To be published in Indoor Air

\title{
INDOOR AIR QUALITY, VENTILATION AND HEALTH SYMPTOMS IN SCHOOLS: AN ANALYSIS OF EXISTING INFORMATION
}

Joan M. Daisey ${ }^{1, \S}$, William J. Angell ${ }^{2}$ and Michael G. Apte ${ }^{1, *}$

${ }^{1}$ Indoor Environment Department, MS: 90-3058, Lawrence Berkeley National Laboratory, Berkeley, CA 94720, U.S.A.

${ }^{2}$ Indoor Air Quality Project, Minnesota Extension Service, University of Minnesota, St. Paul, MN 55108, U.S.A.

${ }^{\S}$ Deceased

KEYWORDS: allergy, asthma, microbiological contaminant, carbon dioxide concentration, formaldehyde, sick building syndrome, ventilation rate

\footnotetext{
*Author to whom correspondence should be addressed.

Address: 1Cyclotron Rd, Berkeley, CA, 94720, USA

E-mail: MGApte@lbl.gov

FAX: $\quad+1510486-6658$
} 


\section{ABSTRACT}

We reviewed the literature on indoor air quality (IAQ), ventilation, and building-related health problems in schools and identified commonly reported building-related health symptoms involving schools until 1999. We collected existing data on ventilation rates, carbon dioxide $\left(\mathrm{CO}_{2}\right)$ concentrations and symptom-relevant indoor air contaminants, and evaluated information on causal relationships between pollutant exposures and health symptoms. Reported ventilation and $\mathrm{CO}_{2}$ data strongly indicate that ventilation is inadequate in many classrooms, possibly leading to health symptoms. Adequate ventilation should be a major focus of design or remediation efforts. Total volatile organic compounds, formaldehyde and microbiological contaminants are reported. Low formaldehyde concentrations were unlikely to cause acute irritant symptoms $(<0.05 \mathrm{ppm})$, but possibly increased risks for allergen sensitivities, chronic irritation, and cancer. Reported microbiological contaminants included allergens in deposited dust, fungi and bacteria. Levels of specific allergens were sufficient to cause symptoms in allergic occupants. Measurements of airborne bacteria and airborne and surface fungal spores were reported in schoolrooms. Asthma and "sick building syndrome" symptoms are commonly reported. The few studies investigating causal relationships between health symptoms and exposures to specific pollutants suggest that such symptoms in schools are related to exposures to volatile organic compounds (VOCs), molds and microbial VOCs, and allergens.

\section{Practical Implications}

The paper summarizes and explores the peer-reviewed literature on indoor air quality (IAQ) in schools, a field that is of increasing interest to the research community, educators and school facilities managers, and the public at large. These experts generally agree that healthy indoor school environments are a necessity if a high standard of education is to be expected. Although peer-reviewed literature on this subject is sparse, there is a clear indication that classroom ventilation is typically inadequate. Researchers observed specific allergens in classrooms at levels sufficient to affect sensitive occupants. Studies of health symptom associations with IAQ conditions in the classroom are very rare, but taken with more general knowledge of IAQ, suggest that improved ventilation and targeted indoor pollutant source reductions could reduce certain occupant symptoms and improve the standard of health of the occupants. 


\section{INTRODUCTION}

As of 1996 there were 88 thousand kindergartens through 12th grade (K-12) public schools in the United States providing daily housing for almost 46 million students and 2.7 million teachers as well as for extracurricular programs, daycare centers, and community programs (USDE, 2000). There is evidence that many school districts in the United States (GAO, 1995) and schools in other countries have significant and serious indoor environmental problems. From the educational standpoint, the indoor air quality and ventilation in school buildings may affect the health of the children and indirectly affect learning performance. Surprisingly, given the magnitude of the school population, information on indoor air quality in schools is very limited. Although a number of individual studies of indoor air quality, ventilation, and health symptoms in schools exist, a comprehensive examination of the existing research has not been compiled. We reviewed the existing published literature on indoor air quality (IAQ), ventilation, and IAQ- and building-related health problems in schools. The objectives of this review were to:

1. Identify the most commonly reported building-related health symptoms involving schools;

2. assemble, evaluate, and summarize existing measurement data on ventilation, carbon dioxide $\left(\mathrm{CO}_{2}\right)$ concentrations and key indoor air pollutants most likely to be related to these symptoms, (e.g., volatile organic compounds (VOCs) and biological contaminants); and

3. summarize existing information on causal relationships between pollutant exposures and health symptoms in schools.

\section{METHODS}

The scientific literature until 1999, published in journals and conference proceedings was searched through a number of electronic databases including Airbase from the Air Infiltration and Ventilation Center, Applied Science and Technology Index; Chemical Abstracts; Concentration of Indoor Pollutants (CIP) Database developed by Lawrence Berkeley National Laboratory; Current Contents; Education Resource Information Center; General Science Index; Inside Information; Inspec; Medline; and Toxline. A wide range of search terms related to buildings, ventilation, IAQ, and health and attendance outcomes in schools were used to explore these databases. A number of document sets were manually searched including: American Society of Heating, Refrigerating, and Air-Conditioning Engineers (ASHRAE) IAQ Conference Proceedings; ASHRAE Journal; ASHRAE Transactions; and U.S. Environmental Protection Agency (EPA) Radon Proceedings. The EPA's School Evaluation Program (SEP) data collected in the early 1990s from 12 schools in Florida, Kansas, New Mexico, and Washington with elevated indoor radon was also examined. In all, over 300 peer-reviewed articles were reviewed and those containing studies of schools including either quantitative evaluations of ventilation or indoor concentrations of $\mathrm{CO}_{2}$, VOCs, or biological contaminants, and/or evaluations of 
building-related health issues were included. The papers were carefully reviewed and those studies with clear methodological flaws were excluded.

Additionally, although not discussed here, 77 Health Hazard Evaluation Reports (HHERs) on educational facilities from the National Institute for Occupational Safety and Health (NIOSH) and 70 reports on IAQ investigations of schools in California were obtained through requests for information to various California state authorities were reviewed. We present this extended review in Daisey and Angell (1988).

\section{Measurements of Ventilation Rates and $\mathrm{CO} 2$ Concentrations in Schools Ventilation Rates}

Ventilation rates have rarely been measured in schools, although inadequate ventilation is often suspected to be an important condition leading to reported health symptoms. ASHRAE Standard 62-1999 (ASHRAE, 1999) recommends a minimum ventilation rate of $8 \mathrm{~L} / \mathrm{s}$-person $(15 \mathrm{cfm} /$ person) for classrooms. Given typical occupant density of 33 per

$90 \mathrm{~m}^{2}\left(1000 \mathrm{ft}^{2}\right)$ and a ceiling height of $3 \mathrm{~m}(10 \mathrm{ft})$, the current ASHRAE standard would require an air exchange rate of about 3 air changes per hour $(\mathrm{ACH})$ for a classroom.

Average ventilation rates and ranges reported in the scientific literature for U.S. and European schools are shown in Figure 1. Three studies were performed in non-complaint schools. Some studies provided only aggregated data while others included data for individual schools. Some data are for the same schools under different conditions such as preand post-radon mitigation.

Turk, et al. (1987b, 1989) reported ventilation measurements made in 6 non-complaint schools in the U.S. Northwest - 2 in Portland, OR and 4 in Spokane, WA. Schools ranged from 3 - 25 years in age, 1 - 3 stories; all had mechanical ventilation systems of some type. Ventilation rates, calculated on a whole building volume basis, ranged from 4.5 L/s-person to $31 \mathrm{~L} / \mathrm{s}-$ person. The whole or average building rate, however, includes unoccupied areas such as hallways and gymnasiums, and, as the authors point out, this average rate overestimates the local ventilation rate of occupied classrooms. For example, in one of the elementary schools, the whole building ventilation rate was $4.5 \mathrm{~L} / \mathrm{s}-$ person while the ventilation rate in an occupied classroom was only $1.6 \mathrm{~L} / \mathrm{s}$-person.

Turk, et al. (1993) also reported ventilation rates measured in 2 schools in Sante Fe, NM, which were being mitigated for high radon concentrations. Twelve pre- and post-radon mitigation ventilation rates were below 3 ACH with one exception.

Nielsen (1984) reported ventilation measurements made in a random selection of 11 schools in Denmark. Measurements were made in 2 classrooms for 3 consecutive days. The average ventilation rate was $6.4 \mathrm{~L} / \mathrm{s}-$ person with a range of $1.8-15.4 \mathrm{~L} / \mathrm{s}-$ person. 


\section{$\mathrm{CO}_{2}$ Concentrations}

Carbon dioxide concentrations are often used as a surrogate of the rate of outside supply air per occupant. Indoor $\mathrm{CO}_{2}$ concentrations above about $1000 \mathrm{ppm}$ are generally regarded as indicative of ventilation rates that are unacceptable with respect to body odors. Concentrations of $\mathrm{CO}_{2}$ below $1000 \mathrm{ppm}$ do not always guarantee that the ventilation rate is adequate for removal of air pollutants from other indoor sources (Seppänen et al., 1999; Apte et al., 2000).

It is difficult to adequately characterize indoor $\mathrm{CO}_{2}$ concentrations since they are a function of occupancy and ventilation rate, both varying as a function of time. Grab samples or other short-term measurements may be inadequate to provide information on the long-term ventilation conditions in schools. There is a great variability in the methods used to characterize the indoor $\mathrm{CO}_{2}$ concentrations in the papers discussed below.

Figures 2 and 3 present the average and ranges of $\mathrm{CO}_{2}$ concentrations reported in the scientific literature for U.S. and Canadian schools, and for European schools, respectively, for both complaint and non-complaint schools. In many of these reports, concentrations are near or only slightly above the ASHRAE standard of 1,000 ppm, regardless of complaint or non-complaint status. $\mathrm{CO}_{2}$ concentrations well above $1000 \mathrm{ppm}$ were also reported for some noncomplaint schools.

Brennan et al. (1991) reported mid-afternoon $\mathrm{CO}_{2}$ measurements in a non-random study of 9 U.S. non-complaint schools. Concentrations ranged from about 400 to $5,000 \mathrm{ppm}($ mean $=1480 \mathrm{ppm}) . \mathrm{CO}_{2}$ concentrations exceeded the $1000 \mathrm{ppm}$ ASHRAE ventilation standard in $74 \%$ of the rooms.

The average $\mathrm{CO}_{2}$ concentrations for 3 non-complaint schools in Alberta, Canada were below 1000 ppm although some measurements exceeded this concentration (Cousins and Collett, 1989). In one portable classroom the average $\mathrm{CO}_{2}$ concentration was $1950 \mathrm{ppm}$. The number of classrooms studied at each school was not provided.

Turk, et al. (1993) reported slightly elevated $\mathrm{CO}_{2}$ concentrations for two schools in New Mexico prior to and after radon mitigation. Fisher et al. (1994), and Thorne (1993) show similar elevated indoor $\mathrm{CO}_{2}$ concentrations prior to radon mitigation, with reductions to levels below $1000 \mathrm{ppm}$ post-mitigation

$\mathrm{CO}_{2}$ concentration measurements reported for a number of mostly non-complaint European schools were near or above $1000 \mathrm{ppm}$ (Figure 3). Two Swedish schools (Norback, 1995) had average concentrations of 1420 and $1850 \mathrm{ppm}$. Median $\mathrm{CO}_{2}$ concentrations were $1070 \mathrm{ppm}$ (range 800 to $1600 \mathrm{ppm}$ ) in a study of 10 Swedish non-complaint schools, and $1100 \mathrm{ppm}$ (range 875 to $2150 \mathrm{ppm}$ ) in 11 schools with higher prevalence of SBS symptoms (Willers et al., 1996). Nielsen et al. (1984) reports a measured showing a $\mathrm{CO}_{2}$ range of 500-1500 ppm (average $=1000 \mathrm{ppm}$ ) in 11 Danish schools. Many of the European measurements were made with colorimetric indicator tubes over a very short time interval. 
Potting, et al. (1987) reported an epidemiological study involving 339 students in 3 Dutch complaint schools (14 classrooms) and 4 schools without teacher complaints (207 controls). All schools were constructed after 1980. Classroom $\mathrm{CO}_{2}$ levels in all of the schools exceeded the Dutch standard of 1200 ppm during 27 to $97 \%$ of the school

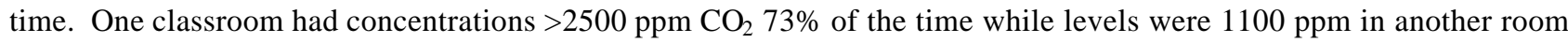
at the beginning of a school day.

Smedje, et al. $(1996,1997)$ reported average and ranges of indoor $\mathrm{CO}_{2}$ concentrations for 96 classrooms in 38 Swedish schools randomly selected from a population of 130 schools; $61 \%$ of them had mechanical supply and exhaust air systems while the remainder had natural ventilation. Concentrations averaged 990 ppm $\mathrm{CO}_{2}$ for the 38 schools, but were above $1000 \mathrm{ppm}$ for $41 \%$ of the measurements (maximum $=2800 \mathrm{ppm}$ ).

In general, $\mathrm{CO}_{2}$ measurements in schools suggest a significant proportion of classrooms probably do not meet the ASHRAE Standard 62-1999 for minimum ventilation rate, at least part of the time. Furthermore, although the data are sparse, it appears that this situation may be more acute in portable classrooms. Ventilation rate measurements support this observation. No evidence suggests that elevated $\mathrm{CO}_{2}$ levels were restricted to complaint schools. However, there have not been any representative surveys of school classrooms to provide information on the distributions of $\mathrm{CO}_{2}$ concentrations or ventilation rates in schools on statewide, regional, or national basis. Concentrations of a variety of pollutants emitted by the occupants and building materials and furnishings will be higher under these conditions than if the ASHRAE ventilation standard were met. Of particular concern is the potential for increased risks of contracting certain communicable respiratory illnesses, such as influenza and common colds in classrooms with low ventilation rates (Fisk 2001).

\section{Indoor Pollutants}

The most commonly measured pollutants in schools were total volatile organic compounds (TVOC), formaldehyde, and biological contaminants. VOCs are suspected as one of the causes of SBS. Measured values of TVOC can vary significantly depending upon the sampling and analysis methods used (Hodgson, 1995). Particularly high TVOC concentrations, above 1 to $2 \mathrm{mg} / \mathrm{m}^{3}$, indicate the presence of strong VOC sources and/or low ventilation.

\section{Total VOCs}

Very few measurements of TVOCs in schools are reported in the archival scientific literature. For the U.S., only three papers were found which reported TVOC measurements and all involved complaint schools. TVOC concentrations in two Southeastern US schools with reported humidity and mold problems ranged from about 1 to 23 $\mathrm{mg} / \mathrm{m}^{3}$ in one school and averaged $1.6 \mathrm{mg} / \mathrm{m}^{3}$ in another (Bayer and Downing, 1992). Black and Worthan (1995) reported average TVOC concentrations of 0.45 and $0.2 \mathrm{mg} / \mathrm{m}^{3}$ under unoccupied and occupied conditions, for a problem school in Washington State after mitigation. Casey, et al. (1995) reported TVOC measurements made in two Las 
Vegas, NV elementary schools during the cooling season. The ventilation systems for the classrooms had been disabled for unknown reasons and the only means of ventilation was infiltration. TVOC levels before the installation and operation of heat recovery ventilators (HRVs) ranged from 0.8 to $2.0 \mathrm{mg} / \mathrm{m}^{3}$. With the HRVs operating, concentrations of TVOC were reduced to $0.75 \mathrm{mg} / \mathrm{m}^{3}$ and $0.45 \mathrm{mg} / \mathrm{m}^{3}$ in the two classrooms.

Cavallo, et al. (1993) reported TVOC concentrations for ten non-complaint schools in Italy. The median concentration reported for the Italian nurseries and kindergartens was $3.6 \mathrm{mg} / \mathrm{m}^{3}$ and lower for primary and secondary schools $\left(0.26 \mathrm{mg} / \mathrm{m}^{3}\right)$, but the upper end of the range was very high, $13.6 \mathrm{mg} / \mathrm{m}^{3}$. The average TVOC for 10 French schools was $0.98 \mathrm{mg} / \mathrm{m}^{3}$ (Laurent, et al., 1993). Norback (1995) reported the range of average TVOC concentrations from 36 classrooms in 6 Swedish primary schools to be quite low, 0.07 to $0.18 \mathrm{mg} / \mathrm{m}^{3}$. Median TVOC (excluding limonene) concentrations were $0.19 \mathrm{mg} / \mathrm{m}^{3}$ (range 0.10 to $0.23 \mathrm{mg} / \mathrm{m}^{3}$ ) in a study of 10 Swedish non-complaint schools, and $0.11 \mathrm{mg} / \mathrm{m}^{3}$ (range 0.07 to $0.21 \mathrm{mg} / \mathrm{m}^{3}$ ) in 11 schools with higher prevalence of SBS symptoms, while outdoor concentrations averaged about $0.09 \mathrm{mg} / \mathrm{m}^{3}$ (Willers et al., 1996). Mean indoor and outdoor kindergarten TVOC concentrations were $0.09 \mathrm{mg} / \mathrm{m}^{3}$ were $0.05 \mathrm{mg} / \mathrm{m}^{3}$, respectively.

\section{Formaldehyde}

Acute symptoms from $\mathrm{HCHO}$ exposures indoors have sometimes been found including eye, nose and throat irritation as well as lower airway and pulmonary effects (Samet, et al., 1988). Acute HCHO toxicity IAQ guidelines for various settings range from 60 to $100 \mu \mathrm{g} / \mathrm{m}^{3}$ (0.055 to $0.08 \mathrm{ppm}$, OEHHA, 1999; WHO, 1987; DNHW, 1987). The most stringent current $\mathrm{HCHO}$ reference exposure level (REL), based upon possible cancer effects, is $3 \mu \mathrm{g} / \mathrm{m}^{3}(0.002 \mathrm{ppm}$; OEHHA, 2000). A recent study suggests that formaldehyde exposures at levels below current guidelines may lead to an increased risk of allergic sensitization of children to common aeroallergens (Garrett, et al., 1999).

Two journal articles and one EPA report reported HCHO measurements in U.S. schools. Black and Worthan (1995) reported measurements made in a complaint school after mitigation. Average concentrations in the school were 0.01 ppm before and during occupancy. Sheldon et al. (1989a, b) measured HCHO in several public buildings including a non-complaint primary school in Washington, D.C., finding one sample with a trace of formaldehyde $(0.012 \mathrm{ppm})$, while all other samples were below the limit of detection $(0.01 \mathrm{ppm})$. Turk, et al. (1987a) reported HCHO measurements for 6 non-complaint schools in the Pacific Northwest where 10 day average concentrations were generally below $0.05 \mathrm{ppm}$.

Average formaldehyde concentrations reported for 10 schools in Milan, Italy (Cavallo, et al., 1993) and 10 schools in Paris, France (Laurent, et al., 1993) were also generally at or near 0.05 ppm. However, some concentrations reported in both studies were above the HCHO irritancy threshold. 
Olsen and Dossing (1982) reported measurements of formaldehyde made in 10 Danish daycare centers. Seven were located in mobile buildings and 3 were in permanent buildings. The average formaldehyde concentration for the mobile buildings was $0.35 \mathrm{ppm}$ (range: $0.20-0.45 \mathrm{ppm}$ ), approximately five times higher than the average of $0.065 \mathrm{ppm}$ for daycare centers in permanent buildings. Mucous membrane irritation of eyes, nose and throat were three times more frequent among the staff in the mobile buildings than the permanent buildings.

Due to the nature of $\mathrm{HCHO}$ as both an acute toxicological agent and as a potential human carcinogen, it is important to consider the above data from both perspectives. Concentrations acceptably low for prevention of acute irritation symptoms may not protect against potential long-term cancer risk. The California Air Resources Board advises that $\mathrm{HCHO}$ concentrations be as low as possible due to the potential cancer risk from repeated exposures (CARB, 1991).

\section{Bioaerosol contaminants}

The term "bioaerosol contaminants" refers to a diverse variety of agents from biological sources found in indoor environments. These contaminants include: (1) viruses; (2) bacteria, including endotoxins from bacteria; (3) allergens, including house dust mite allergens [(Dermatophagoides pteronyssinus allergen I (Der p I) and Dermatophagoides farinae allergen I (Der f I)], and allergens from animal dander [e.g., Felis dosmeticus allergen I (Fel d I)]; and (4) fungi which may contain allergens, toxins, and irritants.

There is evidence that low ventilation rates and other building characteristics can lead to increased incidence of respiratory diseases caused by viruses (Brundage, et al., 1988; Fisk, 2001). No references were found for airborne viral measurements in schools, but total airborne bacteria have been reported in a number of studies. Bacterial endotoxins, present in house dust and airborne particulate matter are thought to cause a range of flu-like symptoms (Rylander, et al. $1989 ;$ 1992), but no references to endotoxin measurements in schools were found.

Exposure to house dust mite allergens can cause asthma and trigger asthma attacks in sensitized subjects (Samet, et al., 1988). House dust mites thrive under conditions of high relative humidities and allergies to them are more frequent in climates with mild humid winters (Reed and Swanson, 1986). Cat and dog allergens found in house dust cause symptoms in many allergic subjects, and can be shed from contaminated clothing in classrooms (Dybendal and Elsayed, 1989; Munir, et al., 1993) causing symptoms in sensitized asthmatic children.

Exposures to mold spores in indoor air can also cause allergic reactions in sensitized subjects, with symptoms such as runny nose, watery eyes, cough, sneezing, and fevers. Water damage in a building often leads to the growth of molds and to airborne exposures to mold spores from genera such as Aspergillus, Alternaria, and Cladosporium. Water damage to buildings was the second most commonly reported building-related problem associated with indoor air problems in the NIOSH HHERs (see Daisey and Angell, 1998). 
However, as discussed in Daisey and Angell (1988), NIOSH generally does not routinely recommend airborne bioaerosol monitoring since lack of findings does not rule out harmful exposures, while visible microbial growth on interior building surfaces usually serves as clear evidence of a potential biological problem. The guidelines published by the American Conference of Governmental Industrial Hygienists' Committee on Bioaerosols share this interpretation; "One should use air sampling as a last resort. Air sampling rarely provides proof of inappropriate exposure to bioaerosols." (ACGIH, 1995). Thus, given physical evidence, quantification of biological contamination can often be skipped in favor of remediation.

\section{Total Airborne Bacteria}

Eight papers were found in scientific journals and conference proceedings in which measurements of airborne bacteria were reported (Bates and Mahaffy, 1996; Black and Worthan, 1995; Cousins and Collett, 1989; Gallup, et al., 1993; Maroni, et al., 1993; Meklin, et al., 1996; Mouilleseaux, et al., 1993; and Thorne, 1993). Typically, only one or a few schools were investigated often with no identification of bacterial species. The reported range varies over two orders of magnitude, from 7 colony forming units $(\mathrm{CFU}) / \mathrm{m}^{3}$ to $19,500 \mathrm{CFU} / \mathrm{m}^{3}$. Occupant density and ventilation rates, strong determinants of total levels of airborne bacteria, were not reported in these studies.

Morey (1984) suggested that concentrations above $1000 \mathrm{CFU} / \mathrm{m}^{3}$ indicate possible microbial contamination warranting further investigation. However, in California, a warmer climate, an average of $1400 \mathrm{CFU} / \mathrm{m}^{3}$ was reported for total bacteria in outdoor air (Gallup, et al., 1993).

When identifications were made, the most commonly observed bacteria in the literature, were Micrococcus and Bacillus species and pigmented gram negative rods such as Flavobacterium species, and coryneforms. Maroni, et al. (1993) reported finding principally species Staphylococcus (85\% of samples), Micrococcus (72\% of samples) and Difteroides (70\% of samples) in Italian classrooms. Mouilleseux, et al. (1993) reported finding Staphylococcus aurus (33\%), Enterobacteria including Escherichia coli (6\%); Streptococcus D (50.6\%). Gallup, et al. (1993) noted that increased counts of "normal" bacteria were observed with increased dust levels, activity, and occupancy.

\section{Dust Mite and Animal Allergens}

Four publications presented measurements of allergens in schools (Bates and Mahaffy, 1996; Dybendal and Elsayed, 1992; Munir, et al., 1993; Smedje, et al., 1996). Exposures to these allergens can cause asthma and trigger asthma attacks in sensitized subjects (Samet, et al., 1988). Many regions have climates that are favorable to growth of dust mites in indoor environments.

Concentrations of more than 2,000 ng Der p I per gram of dust may represent a risk for development of specific IgE to house dust mite allergen in genetically predisposed individuals (Verhoeff, et al., 1994). Concentrations above 10,000 $\mathrm{ng} / \mathrm{g}$ dust of cat or dog allergen are sufficient to cause sensitization and associated risk of asthma in exposed children (Platts-Mills, et al. 1995). 
Bates and Mahaffy (1996) reported measurements of allergens in carpet dusts collected from 7 complaint and 6 noncomplaint classrooms in 6 Florida schools before and after cleaning. All classrooms had level loop pile carpeting. Der p I and Der $f$ I were measured and the sum of both reported; Der p I was reported as the dominant species in all carpet dust samples. Before cleaning, 5 of the classrooms had levels of house dust mite allergen plus cat allergen above 2,000 ng/g dust and 2 had levels above 9,000 ng/g. The complaint room average Der p I and Der $\mathrm{f}$ I loadings were $5000 \pm$ $5000 \mathrm{ng} / \mathrm{g}$ dust and the non-complaint rooms were $210 \pm 210 \mathrm{ng} / \mathrm{g}$ dust. Cleaning substantially reduced the levels.

Floor dust in 60 classrooms in 10 Norwegian schools was analyzed for Fel d I, Der p I and Der f I. Fel d I was detected in all classrooms and ranged from 40 to $1100 \mathrm{ng} / \mathrm{gram}$ dust (Dybendal and Elsayed, 1992). On average, Fel d I loadings were 11 times higher in carpeted areas compared to smooth floors. Der p I and Der f I loadings were very low. A significantly higher content of allergens per gram of dust was also found for carpeted than smooth floors, as measured by basophil histamine release.

Dust samples from furniture and floors in 29 classrooms in 4 Swedish schools were assayed for Fel d I and dog allergen Can f I (Munir, et al., 1993). Fel d I concentrations in chair, table, and floor samples were 1000, 500, and 100 ng/g dust, respectively. Can f I loadings were higher than Fel d I in the chair and the floor samples. The authors concluded these two major allergens were potentially at levels sufficient to sensitize children and to induce asthma in most children who are allergic to cats or dogs. Cat and dog allergens in fine dust samples from 96 classrooms in 38 randomly selected Swedish schools averaged $132 \mathrm{ng} / \mathrm{g}$ while dog allergen averaged $625 \mathrm{ng} / \mathrm{g}$ with a maximum of 3,900 ng /g dust (Smedje, et al., 1996).

The range of measured allergens in dust presented in the four above-mentioned studies varied and was dependent on the specific allergen and the condition of the classrooms. Clearly, the floor surface type and level of cleaning were important factors in maintaining low allergen levels. Carpeted floors contained a significantly higher content of allergens per gram of dust and cleaning reduced the levels of mite allergen.

Fungi

Rao, et al. (1996) recently found that existing quantitative standards and guidelines for total fungi in indoor air range from $<100 \mathrm{CFU} / \mathrm{m}^{3}$ to $>1000 \mathrm{CFU} / \mathrm{m}^{3}$ as the upper limit for non-contaminated indoor environments, based primarily on baseline data rather than health effects information. Limitations in the standards and guidelines include reliance on short-term grab samples analyzed only by culture, lack of standardized protocols for data collection, analysis and interpretation, and the lack of connection to human dose-response data. In addition, since the toxin concentration in spores is most likely independent of viability, measurements of culturable fungi may not adequately reflect the potential for health problems. 
Total airborne fungi in schools were reported in ten papers (Bates and Mahaffy, 1996; Bayer, et al., 1995; Black and Worthan, 1995; Cousins \& Collett, 1989; Dotterud, et al., 1996; Henkel and Angell, 1999; Maroni, et al., 1993; Meklin, et al., 1996; Mouilleseaux, et al., 1993; and Smedje, et al., 1996, 1997). Bates and Mahaffy (1996) investigated airborne and surface fungi in 13 classrooms in 6 Florida schools. Health complaints included stuffy sinuses, sore throats, respiratory illnesses, lethargy, itchy eyes and runny noses. Concentrations were $>1,000 \mathrm{CFU} / \mathrm{m}^{3}$ in one complaint and one non-complaint room, while in all other classrooms they were $<700 \mathrm{CFU} / \mathrm{m}^{3}$. Concentrations were generally higher in the outdoor air.

Average and maximum total viable molds measured in 96 classrooms in 38 randomly selected Swedish schools were $500 \mathrm{CFU} / \mathrm{m}^{3}$ and 4,500 CFU/m³, respectively (Smedje, et al. 1996, 1997). Gravesen, et al. (1986) measured viable molds in dusts from 36 carpeted rooms and 13 non-carpeted rooms in 21 Danish schools. Significantly greater $(\mathrm{p}=0.002)$ mold colony counts were found in the carpet dust $(\sim 1900 \mathrm{CFU} / \mathrm{g}$. dust) than the bare floors $(\sim 950 \mathrm{CFU} / \mathrm{g}$. dust). The most prevalent microfungal genera were Penicillium, Fusarium, Alternaria and Cladosporium.

\section{Relationships Between Health Symptoms, Ventilation and Other Indoor Environmental Factors in Schools}

As of 1999, only two studies, both European, have investigated the relationships between symptom prevalences and ventilation rate or $\mathrm{CO}_{2}$ concentrations in schools. Myhrvold, et al. (1996) studied 22 classrooms in 5 Norwegian schools renovated with the objective of improving indoor air quality. Pre- and post-renovation measurements were made, including health symptom questionnaires and performance tests administered to 550 students, and measurements of $\mathrm{CO}_{2}$ concentrations. These investigators found a statistically significant partial correlation (one way ANOVA, $\mathrm{p}<$ 0.001) between symptoms of headaches, dizziness, heavy headed, tiredness, difficulties concentrating, unpleasant odor, and high $\mathrm{CO}_{2}$ concentrations (1500 - 4000 ppm compared to concentrations below 1500 ppm). Health symptoms characterized as "irritations of the upper airways" were also higher at higher $\mathrm{CO}_{2}$ concentrations $(\mathrm{p}=0.024)$. Reduced performance on the Swedish Performance Evaluation System test was also observed at higher concentrations of $\mathrm{CO}_{2}$.

On the other hand, an epidemiological study in 3 complaint and 4 non-complaint Dutch schools (14 classrooms total) assessed relationships between SBS symptom complaints of children and $\mathrm{CO}_{2}$ levels and indoor climate (Potting, et al., 1987). The complaint of "bad odor of the air" was associated with high $\mathrm{CO}_{2}$ levels.

The results of these two available studies in schools were inconsistent, as might be expected since ventilation rate and $\mathrm{CO}_{2}$ concentrations are only surrogates for the actual agents that might be causing the symptoms. Other study limitations include inadequate characterization of indoor ventilation rates, $\mathrm{CO}_{2}$ and indoor contaminant levels, and health outcome, as well as small sample sizes and inadequate control for confounding,. A comprehensive review is available, however, on relations between ventilation rates and occupant health in twenty studies, mostly among adults in 
office and other work settings. This review found consistent relations between ventilation rates below $10 \mathrm{~L} / \mathrm{sec}$ per person ventilation rates and increased symptoms among occupants (Seppanen et al. 2000). Ventilation rates increased above $10 \mathrm{~L} / \mathrm{sec}$ per person, even up to 20 or $30 \mathrm{~L} / \mathrm{sec}$ per person, were associated in some, but not all, studies, with further significant reductions in occupant symptoms. Findings of studies using $\mathrm{CO}_{2}$ measurements to approximate ventilation rates generally agreed, but not as consistently. Corroborating the Seppanen et al. review conclusions, analysis of a large data set on adults in office buildings found statistically significant, dose-dependant, increases of up to a factor of six in the risk of building-related lower respiratory and mucous membrane irritation symptoms when average workday indoor $\mathrm{CO}_{2}$ concentrations increased by $420 \mathrm{ppm}$ above outdoor levels, concentrations still below the ASHRAE 62-1999 standard of 1000 ppm (Apte et al., 2000). Although the office environment differs from school environments, similar exposure and occupant health response mechanisms are likely to occur.

Several studies have assessed relationships of various health outcomes among students with indoor environmental factors in schools. In a study of 579 asthmatic Danish children, Hansen, et al. (1987) reported an increased severity of asthma in schools with carpet compared to those with no carpet. This association was especially strong and statistically significant $(\mathrm{p}=0.02)$ for the children who had no carpet in their rooms at home and had no pets.

Norback and Torgen (1987) compared 59 staff member questionnaire responses (94\% response rate) in two Swedish schools with wall to wall carpeting against 133 from four schools without carpeting. A questionnaire was administered $(\mathrm{N}=141)$ in 1982 and then again in 1986 after carpeting was removed. Results of the questionnaire for 1982 (Table 2) showed significantly higher frequency of health complaints in carpeted classrooms ( $\mathrm{p} \leq 0.03$ ). Four years later, 37 of the 59 staff in the two schools that had carpet removed and 81 of the staff in the four schools without carpeting were resurveyed. Some health complaints remained significantly higher among those that previously had carpeting ( $\mathrm{p} \leq 0.02)$.

Koskinen, et al. (1997) compared respiratory symptoms and infections in children (3-7 years old) in two daycare centers with visible mold growth on interior walls (exposed children) to those in two reference daycare centers (nonexposed children). Parents recorded their children's $(\mathrm{N}=229)$ health symptom status in diary questionnaires during two study periods. During the first period, the children in the two daycare centers with mold problems (exposed) had a significantly increased risk of sore throat, purulent and non-purulent nasal discharge, nasal congestion, hoarseness and common cold than those in the two reference daycare centers (non-exposed). During the second follow-up period, a significantly increased risk of purulent nasal discharge, nasal congestion, hoarseness and cough was observed for the exposed populations compared to the unexposed. Overall morbidity for respiratory symptoms and common cold were higher in the daycare centers with the mold than in the two reference day care centers. This study was consistent with the results of an earlier comparative study of two daycare centers, one with and one without mold problems (Koskinen, et al., 1995). In this earlier study, absenteeism in the mold-exposed daycare center was almost double that in the nonexposed daycare center. 


\section{Relationships Between Health Symptoms and Measured Exposures to Environmental Pollutants in Schools}

Most studies of health symptoms and pollutant exposures in classrooms have used surrogates of exposure (e.g., presence of molds on walls), have measured a single pollutant, or have assumed that whatever mitigation measures were taken were effective in reducing or eliminating symptoms. We found only three epidemiological studies in schools in which multivariate regression analyses were used to more rigorously examine relationships between health symptoms and measured exposures to more than one pollutant. Table 3 summarizes key features of these studies.

In a longitudinal study on the effects of removal of wall-to-wall carpeting, Norback, et al., (1990) reported on relationships between prevalences of SBS symptoms among personnel in 6 primary schools in Sweden, indoor exposures and personal factors. Chronic SBS symptoms (airway irritation or congestion; headache, tiredness, sensation of getting a cold, nausea; and eye irritation/swollen eyelids) reported in both 1982 and in 1986 were related to VOC concentrations, previous occupancy in a classroom with wall-to-wall carpeting, hyperreactivity, and psychosocial factors. The incidence of new SBS symptoms (only eye irritation/swollen eyelids) reported in 1986 but not in 1982, was related to the concentration of respirable dust, current smoking, and the psychosocial climate.

In a large study of asthma symptoms in 1410 school employees in 38 Swedish schools, Smedje, et al. (1996) found no statistically significant relationships (at the $95 \%$ confidence level) between asthma and many commonly measured environmental factors, e.g., $\mathrm{CO}_{2}$, air exchange rates, humidity. However higher concentrations of molds and of 4 microbial VOCs were significantly related to asthma in the 1410 school employees, even after controlling for other factors, i.e., allergies, stressful work situation, and recent repainting of homes. More recently, Smedje, et al. (1997) reported statistically significant relationships between current asthma in secondary school pupils and school exposures to formaldehyde, VOCs (sum of 14 compounds, 1 week sample), viable bacteria (in air), viable molds (in air) and cat allergen in settled dust. Evidence of a dose-response relationship with these variables was also reported.

\section{Summary and Conclusions}

The available measurements of ventilation rates and $\mathrm{CO}_{2}$ concentrations in schools suggest that, based upon the current ASHRAE ventilation standard, many classrooms are not adequately ventilated. Although, results from the few studies in schools have been inconsistent in associating ventilation rates or $\mathrm{CO}_{2}$ concentrations and symptoms, a broad literature review for indoor environments more generally suggests a consistent relationship (Seppanen et al. 2000). These findings, mostly in adults, would apply to school children with two reasonable assumptions: that exposures in schools related to ventilation rates are similar to those in offices, and that children would be at least as sensitive as adults to these exposures. The findings of Seppanen et al (2000), together with the data on ventilation inadequacy in current schools, strongly suggest a widespread environmental inadequacy in schools likely to be related to increased 
symptoms in schoolchildren. Since the first line of defense against poor indoor air quality in classrooms is adequate ventilation, this should be a major focus of design or remediation efforts.

The pollutants most commonly measured in schools were TVOC, formaldehyde and microbiological contaminants. In most cases, health symptoms were not measured in these studies. The majority of the formaldehyde measurements, particularly more recent measurements, were below $0.05 \mathrm{ppm}$. Although formaldehyde levels were generally low, recent research suggests that even low levels may lead to an increased risk of sensitization to allergens. Furthermore, formaldehyde is listed as a probable human carcinogen; therefore, formaldehyde levels in schools should be kept very low. The most commonly measured microbiological contaminants measured in schools were allergens in deposited dust (e.g., house dust mite allergen), fungi, and bacteria. Levels of specific allergens in deposited dust were often high enough to cause allergy symptoms in allergic occupants. Fungi have been measured in air and observed growing on surfaces. However, air measurements were generally low and are not recommended because of limitations of sampling and analyses methods. Bacteria have also been measured in some schools but were not generally speciated. Without speciation of bacteria such measurements are of little use since many species are relatively harmless. Lack of speciation also limits our ability to infer whether the bacteria may be the cause of health symptoms.

IEQ related health symptom studies were rarely conducted up to 1999 when this review ends. It is likely that more studies in this important area will be conducted in time. Asthma and SBS were the most commonly reported health symptoms investigated in schools. The few studies in which exposure and symptoms were simultaneously investigated suggest that exposures to VOCs, molds and microbial VOCs, and allergens generally measured in classroom floor dust, are related to asthma, SBS and other respiratory symptoms. There is some indication in the literature that carpets in the classroom are a causal factor for health symptoms. The particular pollutants causing symptoms may differ among schools.

\section{Research Needs}

This review shows that the state of knowledge regarding IAQ in schools is very limited. With the possible exception of the early NIOSH investigations not reported in the peer-reviewed literature, there has been no consistent approach to evaluations of IAQ and health outcomes in schools. Many of the existing studies lack the rigor and quality necessary to adequately address the problem. In addition, although there is some effort to identify the IAQ problems in schools, there are no programs currently in place in the U.S. at the national or state level to improve the indoor environmental quality in schools.

More studies are needed in which relations between symptoms and measured exposures to multiple specific pollutants are investigated. Furthermore, quantitative information is needed on exposure-health response relationships for specific pollutants suspected to cause health symptoms, in order to provide a sound basis for setting standards for schools and for insuring cost-effective mitigation measures. Improved methods for exposure measurements, 
particularly those that provide more speciation of fungi and bacteria and longer sampling times are needed. Finally, although there is evidence that many schools are not adequately ventilated, the extent of the problem is not known. Careful and thorough measurements of ventilation rates and/or $\mathrm{CO}_{2}$ levels in a representative sample of schools would provide much needed information on the fraction of schools with this problem.

In closing, although more studies are needed to determine the extent of IAQ problems in schools, evidence shows that ventilation rates in new and existing schools often do not meet the minimum ASHRAE guidelines, and this may be related to significant increases in symptoms among children and teachers in schools. It is clear that programs should be put in place to ensure that all schools provide necessary ventilation.

\section{ACKNOWLEDGMENTS}

This research was supported the California Environmental Protection Agency, Office of Environmental Health Hazard Assessments and by the Office of Energy Efficiency and Renewable Energy, Office of Building Technology, State and Community Programs, U.S. Department of Energy under Contract No. DE-AC03-76SF00098. We would like to thank William Fisk, Al Hodgson, and Mark Mendell for their careful reviews of this manuscript.

\section{Literature Cited}

Apte, M.G., Fisk, W.J., and Daisey, J.M. (2000) "Associations Between Indoor CO2 Concentrations and Sick Building Syndrome Symptoms in US Office Buildings: An Analysis of the 1994-1996 BASE Study Data," (LBNL 44385) Indoor Air, 10:246-257.

ACGIH. (1995) American Conference of Governmental Industrial Hygienists Bioaerosol Committee. Guidelines for the Assessment of Bioaerosols in the Indoor Environment. Cincinnati, OH, USA.

ASHRAE (1999) Ventilation for Acceptable Indoor Air Quality, Standard 62-1999, American Society for Heating, Refrigerating and Air Conditioning Engineers, Atlanta, GA.

Bates, J.M. and Mahaffy, D.J. (1996) "Relationships of reported allergy symptoms, relative humidity and airborne biologicals in thirteen Florida classrooms," Proceedings of Indoor Air '96: The 7th International Conference on Indoor Air Quality and Climate, Nagoya, Japan, July, 1996, Vol. 1, 551-556.

Bayer, C.W., Crow, S.A. and Noble, J.A. (1995) "Production of volatile emissions by fungi," Proceedings, ASHRAE IAQ 95 Conference, 101-110.

Bayer, C.W. and Downing, C.C. (1992) "Indoor conditions in schools with insufficient humidity control," Proceeding of IAQ 92: Environments for People, Atlanta, GA, American Society of Heating, Air Conditioning, and Refrigerating Engineers, 197-200.

Black, M.S., and Worthan, A. (1995) "Development of a school reoccupancy plan following evacuation due to IAQ complaints - A case study," Proceeding of the ASHRAE IAQ'95 Conference, 25-28.

Brennan, T., Clarkin, M., Turner, W., Fisher, G. and Thompson, R. (1991) "School buildings with air exchange rates that do not meet minimum professional guidelines or codes and implications for radon control," Proceedings of ASHRAE IAQ 91 Healthy Buildings, Atlanta, GA, ASHRAE, 228-229.

Brundage, J.F., Scott, R.M. and Lednar, W.M., Smith, D.W. and Miller, R.N. (1988) "Building-associated risk of febrile acute respiratory diseases in army trainees," Journal of the American Medical Association, 259(14): 2108-2112.

CDNHW (1987) Exposure Guidelines for Residential Indoor Air Quality. Ottawa. Canada Department of National Health and Welfare 
CARB (1991) Formaldehyde in the Home, Indoor Air Quality Guideline No. 1 and Supplement, California Air Resources Board, Research Division, Sacramento, CA, September, 1991. http://arbis.arb.ca.gov/research/indoor/formald.htm

Casey, M.E., Braganza, E.B., Shaughnessey, R.J. and Turk, B.H. (1995) "Ventilation improvements in two elementary school classrooms," In: Proceedings, Engineering Solutions to Indoor Air Quality Problems Symposium, Pittsburgh, PA, Air and Waste Management Association.

Cavallo, D., Alcini, D., de Bortoli, M., Carrettoni, D., Carrer, P., Bersani, M. and Maroni, M. (1993) “Chemical contamination of indoor air in schools and office buildings in Milan, Italy." In: Proceedings of Indoor Air '93: The 6th International Conference on Indoor Air Quality and Climate, Helsinki, Finland, Vol. 2, 45-49.

Cousins, D.M. and Collett, C.W. (1989) "Indoor air quality in 12 schools: A case study," Proceedings of ASHRAE Conference IAQ'87, The Human Equation: Health and Comfort, 104-108.

Daisey, J.M. and W. J. Angell. (1998) A Survey and Critical Review of the Literature on Indoor Air Quality, Ventilation and Health Symptoms in Schools, Lawrence Berkeley National Laboratory Report No. LBNL-41517.

Dotterud, L.R., Vorland, L.H. and Falk, E.S. (1996) "Mould allergy in school children in relation to airborne fungi and residential characteristics in homes and schools in Northern Norway," Indoor Air, 6, 71-76.

Dybendal, T. and Elsayed, S. (1992) "Dust from carpeted and smooth floor. V. Cat (Fel d I) and mite demonstration of the basophil histamine release induced by dust from classrooms," Clinical and Experimental Allergy, 22, 11001106.

Dybendal, T., Vik, H. and Elsayed, S. (1989) "Dust from carpeted and smooth floors. 2. Antigenic and allergenic content of dust vacuumed from carpeted and smooth floors in schools under routine cleaning schedules," Allergy, 44, 401-411.

Fisher, E., Ligman, B., Brennan, T., Shaughnessy, R., Turk, B. and Snead, B. (1994) "Radon mitigation in schools utilizing heating, ventilation, and air conditioning systems," Radiation Protection Dosimetry, 56 (1-4), $51-54$.

Fisk, W.J. (2001) "Estimates of potential nationwide productivity and health benefits from better indoor environments: an update," Indoor Air Quality Handbook., eds. J.Spengler, J.M. Samet, and J.F. McCarthy, McGraw Hill, New York.

GAO (1995) Conditions of America's Schools (GAO/HEHS-95-61), America's Schools Report Differing Conditions, U.S. General Accounting Office, Available, 202-512-6000.

Gallup, J.M., Zanolli, J. and Olson, L. (1993) "Airborne bacterial exposure: preliminary results of volumetric studies performed in office buildings, schools, and homes in California," In: Proceedings of Indoor Air '93: The 6th International Conference on Indoor Air Quality and Climate, Helsinki, Finland, Vol. 4, 167-170.

Garrett, M.H., Hooper, M.A., Hooper, B.M., Rayment, P.R., Abramson, M. J. (1999) "Increased risk of allergy in children due to formaldehyde exposure in homes," Allergy, 54,330-337.

Gravesen, S., Larsen, L., Gyntelberg, F. and Skov, P. (1986) "Demonstration of microorganisms and dust in schools and offices," Allergy, 41(7), 520-525.

Hansen, L., Bach, E., Kass Ibsen, K. and Osterballe, O. (1987) “Carpeting in schools as an indoor pollutant,” In: Indoor Air '87: Proceedings of 4th International Conference on Indoor Air Quality and Climate, Berlin (West), Institute of Water, Soil and Air Hygiene, Vol. 2, 727-731.

Henkel, CL. and Angell, WJ. (1999) "Survey of indoor air quality and related complaints and building factors in Minnesota Schools," In: Proceedings of Indoor Air '99: The 8th International Conference on Indoor Air Quality and Climate, Edinburgh, Scotland, Vol. 4: 987-992.

Hodgson, A.T. (1995) "A review and a limited comparison of methods for measuring total volatile organic compounds in indoor air," Indoor Air, 5, 247-257.

Koskinen, O., Husman, T., Hyvarinen, A., Reponen, T., and Nevalainen, A. (1995) "Respiratory symptoms and infections among children in a day-care center with mold problems," Indoor Air, 5, 3-9.

Koskinen, O.M., Husman, T.M., Hyvarinen, A.M., Reponen, T.A. and Nevalainen, A.I. (1997) "Two moldy day-care centers: a follow-up study of respiratory symptoms and infections," Indoor Air, 7, 262-268. 
Laurent, A.M., Person, A., Petit-Coviaux, F., Le Moullec, Y., and Festy, B. (1993) "Chemical characterization of indoor air quality inside schools in Paris," In: Proceedings of Indoor Air '93: The 6th International Conference on Indoor Air Quality and Climate, Helsinki, Finland, Vol. 3: 23-28.

Maroni, M., Bersani, M., Cavallo, D., Anversa, A., and Alcini, D. (1993) "Microbial contamination in buildings: comparison between seasons and ventilation systems," In: Proceedings of Indoor Air '93: The 6th International Conference on Indoor Air Quality and Climate, Helsinki, Finland, July, 1993, Vol. 4, 137-142.

Meklin, T., Taskinen, T. and Nevalainen, A. (1996) "Microbial characterization of four school buildings," In: Proceedings of Indoor Air '96: The 7th International Conference on Indoor Air Quality and Climate, Nagoya, Japan, July, 1996, Vol. 2, 1083-1088.

Morey, P.R. (1984) "Case presentation: problems caused by moisture in occupied office buildings," Annals of the American Conference of Industrial Hygienists, 10, 121-127.

Mouilleseaux, A., Squinazi, F., and Festy, B. (1993) "Microbial characterization of air quality in classrooms," In: Proceedings of Indoor Air '93: The 6th International Conference on Indoor Air Quality and Climate, Helsinki, Finland, July, 1993, Vol. 4, 195-200.

Munir, A.K., Einarsson, R., Schou, C. and Drebork, S.K (1993) "Allergens in school dust. I. The amount of major cat (Fel d I) and $\operatorname{dog}$ (Can f I) allergens in dust from Swedish schools is high enough to probably cause perennial symptoms in most children with asthma who are sensitized to cat and dog," Journal of Allergy and Clinical Immunology, 91, 1067-1074.

Myhrvold, A.N., Olsen, E., and Lauridsen, O. (1996) "Indoor environment in schools - pupils health and performance in regard to CO2 concentrations," Proceedings of Indoor Air '96: The 7th International Conference on Indoor Air Quality and Climate, Nagoya, Japan, July, 1996, Vol. 4, 369-374.

Nielsen O. (1984) "Quality of air and the amount of fresh air in classrooms," Indoor Air: Buildings, Ventilation and Thermal Climate. Berglund, B., Lindvall, T. and Sundell, J., Eds., Swedish Council for Building Research, 5, 221226.

Norback, D. and Torgen, M. (1987) "A longitudinal study of symptoms associated with wall-to-wall carpets and electrostatic charges in Swedish school buildings," Indoor Air '87: Proceedings of 4th International Conference on Indoor Air Quality and Climate, Berlin (West), Institute of Water, Soil and Air Hygiene, vol. 3, 357-361.

Norback, D., Torgen, M. and Edling, C. (1990) "Volatile organic compounds, respirable dust, and personal factors related to prevalence and incidence of sick building syndrome in primary schools," Br J Ind Med, 47, 733-741.

Norback, D. (1995) "Subjective indoor air quality in schools - the influence of high room temperature, carpeting, fleecy wall materials and volatile organic compounds," Indoor Air, 5, 237-246

OEHHA (1999) Air Toxics Hot Spots Program Risk Assessment Guidelines Part I. Technical Support Document for the Determination of Acute Reference Exposure Levels for Airborne Toxicants, Appendix C, (March 1999), California Office of Environmental Health Hazard Assessment, Sacramento, CA. http://www.oehha.ca.gov/air/acute_rels/index.html.

OEHHA (2000) Air Toxics Hot Spots Program Risk Assessment Guidelines Part III. Technical Support Document for the Determination of Non-cancer Chronic Reference Exposure Levels for Airborne Toxicants, Appendix C, (May, 2000), California Office of Environmental Health Hazard Assessment, Sacramento, CA. http://www.oehha.ca.gov/air/chronic_rels/index.html.

Olsen, J.H. and Dossing, M. (1982) "Formaldehyde induced symptoms in day care centers," American Industrial Hygiene Association Journal, 43, 366-370.

Platts-Mills, T.A.E., Sporik, R., Ingram, J.M., and Honsinger, R. (1995) "Dog and cat allergens and asthma among school children in Los Alamos, New Mexico, USA - Altitude 7,200 feet," International Archives of Allergy and Immunology, 107 (1-3), 301-303.

Potting, J., van de Sandt, P., ter Haar Romeny-Wacher, I., Brunekreef, B. and Boleij, J.S.M. (1987) "Health complaints, $\mathrm{CO} 2$ levels and indoor climate in Dutch schools," In: Indoor Air '87: Proceedings of 4th International Conference on Indoor Air Quality and Climate, Berlin (West), Institute of Water, Soil and Air Hygiene, Vol. 3, 582-586.

Rao, C.Y., Burge, H.A. and Chang. J.C.S. (1996) "Review of quantitative standards and guidelines for fungi in indoor air," Journal of the Air \& Waste Management Association, 46, 899-908. 
Reed, C.E. and Swanson, M.C. (1986) "Indoor allergens: identification and quantification," Environment International, 12, 115-120.

Rylander, R., Sorensen, S., Goto, H., Yuasa, K., Tanaka, S. (1989) "The importance of endotoxin and glucan for symptoms in sick buildings," In: Present and Future of Indoor Air Quality, Proceedings of the Brussels Conference, Bieva, C.J., Coutois, Y., and Govaerts, M., Eds., Excerpta Medica, New York, 1989, 219-226.

Rylander, R., Persson, K., Goto, H. and Tanaka, S. (1992) "Airborne beta-1,3-glucan may be related to symptoms in sick buildings" Indoor Environment, 1” 263-267.

Samet, J.M., Marbury, M.C. and Spengler, J.D. (1988) "Health effects and sources of indoor air pollution, Part II," American Review of Respiratory Disease, 137, 221-242.

Seppänen, O.A., Fisk, W.J., and Mendell, M.J. (1999) "Association of ventilation rates and $\mathrm{CO}_{2}$ concentrations with health and other responses in commercial and institutional buildings," Indoor Air, 9, pp 226-252.

Shaughnessy, R.J., Turk, B., Levetin, E., Brennan, T., Fisher, E. and Ligman, B. (1993) Impact of ventilation/pressurization on indoor air contaminants in schools, Washington, DC, U.S. EPA.

Sheldon, L.S., Handy, R.W., Hartwell, T.D., Whitmore, R.W. and Zelon, H.S. (1989a) Indoor Air Quality in Public Buildings, Vol. 1, Washington, DC, U.S.EPA-Environmental Monitoring Systems Laboratory, NTIS/PB89-102503.

Sheldon, L.S., Zelon, H.S., Sickles, J., Eaton, C. and Hartwell, T. (1989b) Indoor Air Quality in Public Building, Vol. 2, Washington, DC, U.S. EPA-Environmental Monitoring Systems Laboratory, NTIS/PB89-102511.

Smedje, G., Norback, D., and Edling, C. (1997) "Subjective indoor air quality in schools in relation to exposure," Indoor Air, 7, 143-150.

Smedje, G., Norback, D., Wessen, B. and Edling, C. (1996) "Asthma among school employees in relation to the school environment," In: Proceedings of Indoor Air '96: The 7th International Conference on Indoor Air Quality and Climate, Nagoya, Japan, July, 1996, Vol. 1, 611-616.

Thorne, P.S. (1993) "Sump additives as a source of bioaerosols in a school building," Veterinary and Human Toxicology, 35 (2), 141-143.

Turk, B.H., Brown, J.T., Geisling-Sobotka, K., Froelich, D.A., Grimsrud, D.T., Harrison, J., Koonce, J.F., Prill, R.J., and Revzan, K.L. (1987a) Indoor air quality and ventilation measur,ments in 38 Pacific Northwest Commercial Buildings, Lawrence Berkeley National Laboratory Report No. LBNL-22315.

Turk, B.H., Grimsrud, D.T., Brown, J.T., Geisling-Sobotka, K., Harrison, J. and Prill, R.J. (1987b) "Commercial building ventilation rates and particle concentrations," In: Proceedings of Indoor Air '87: The 4th International Conference on Indoor Air Quality and Climate, vol. 1, 610-614, West Berlin, West Germany.

Turk, B.H., Grimsrud, D.T., Brown, J.T., Geisling-Sobotka, K., Harrison, J. and Prill, R.J. (1989) "Commercial building ventilation rates and particle concentrations," ASHRAE Transactions, 95: 422-433.

Turk, B.H., Powell, G., Fisher, E., Ligman, B., Harrison, J., Brennan, T. and Shaughnessy, R. (1993) "Improving general indoor air quality while controlling specific pollutants in schools," In: Proceedings of Indoor Air '93: The 6th International Conference on Indoor Air Quality and Climate, Helsinki, Finland, Vol. 6, 705-710.

USDE (2000) State Profiles of Public Elementary and Secondary Education, 1997-97, US Department of Education, Washington, DC. http://nces.ed.gov/pubs2000/stateprofiles/.

Verhoeff, A.P., Van Strien, T.T., Van Wijnen, J.H. and Brunekreef, B. (1994) "House dust mite allergen (Der p I) and respiratory symptoms in children: a case-control study," Clinical and Experimental Allergy, 24, 1061-1069.

WHO (1987) Air quality guidelines for Europe. World Health Organization, WHO Regional Publications, European Series No. 23, Copenhagen.

Willers, S., Andersson, S., Andersson, R., Jorgen, G., Sverdrup, C., and Rosell, L. (1996) "Sick Building Syndrome Symptoms among the Staff in Schools and kindergartens: are the Levels of Volatile Organic Compounds and Carbon Dioxide Responsibe?," Indoor Built Environ, 5:232-235. 


\section{Tables}

Table 1. Comparison of frequency of faculty and student health symptoms experienced in three New York complaint schools and a control school ${ }^{\mathrm{a}}$.

\begin{tabular}{lcccc}
\hline Symptom & \multicolumn{2}{c}{ Complaint Schools } & \multicolumn{2}{c}{ Control School } \\
& Faculty & Students $^{\text {b. }}$ & Faculty & Students ${ }^{\text {b. }}$ \\
\hline Stuffy or runny nose or congestion & $22 \%$ & $26 \%^{\text {b. }}$ & $14 \%$ & $27 \%$ \\
Sore or dry throats & 36 & 38 & 18 & 26 \\
Dry or itchy eyes & 36 & 39 & 12 & 12 \\
Coughs & 24 & 31 & 10 & 26 \\
Headaches & 37 & 51 & 24 & 30 \\
\hline
\end{tabular}

${ }^{\mathrm{a}}$ Percent of subjects reporting they temporally experienced the symptom at school, from Gorman and Singal, 1984.

There were 376 faculty respondents (response rate of $77 \%$ of 486), and 2744 students (response rate of $62 \%$ of 4411). ${ }^{\mathrm{b}}$ Reported by parents

Table 2. Symptom frequencies ${ }^{\mathrm{a}}$ among school personnel with wall-to-wall carpet in their classrooms in comparison with school personnel with hard plastic floor coverings, in $1982^{\mathrm{b}}$.

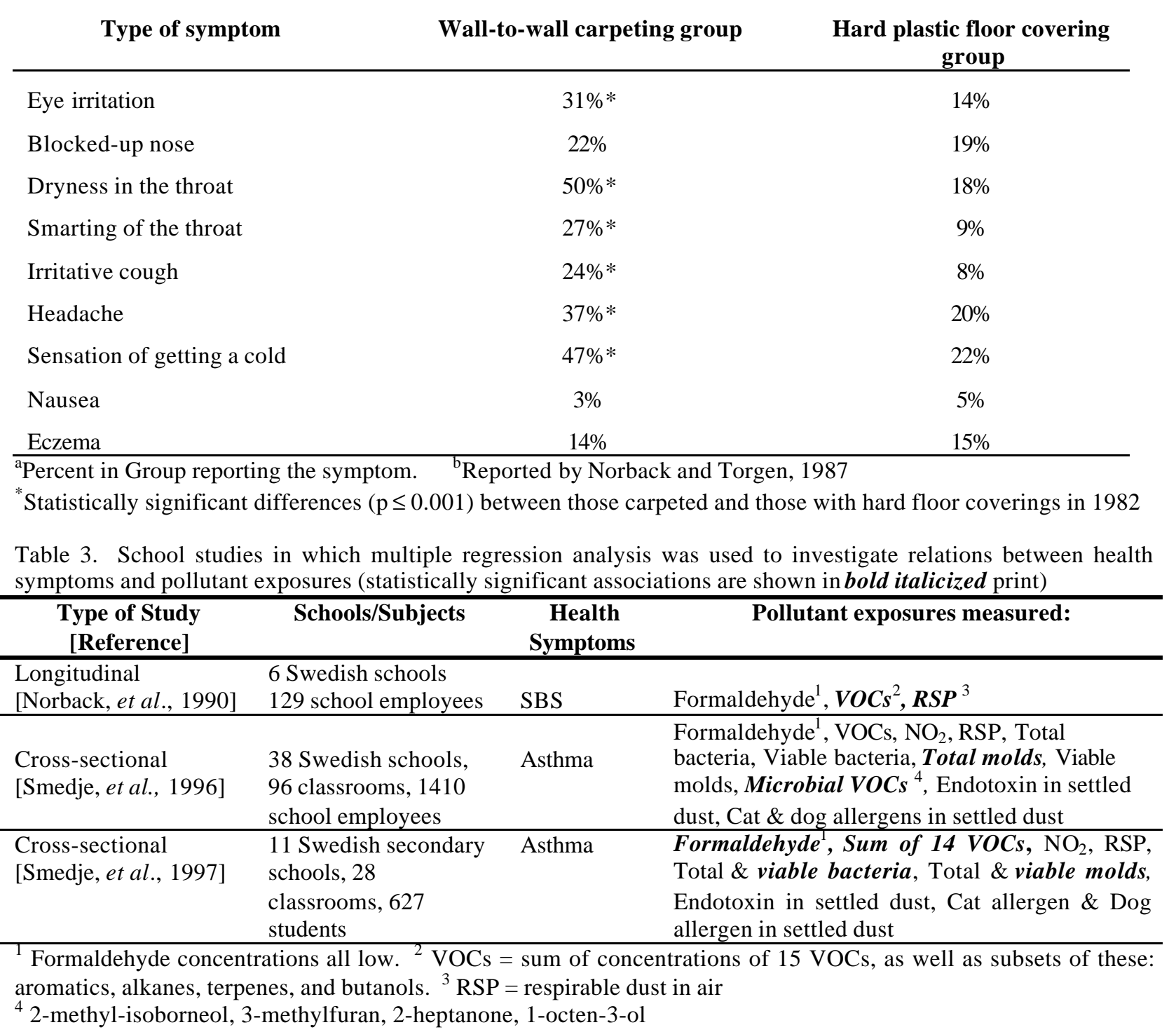




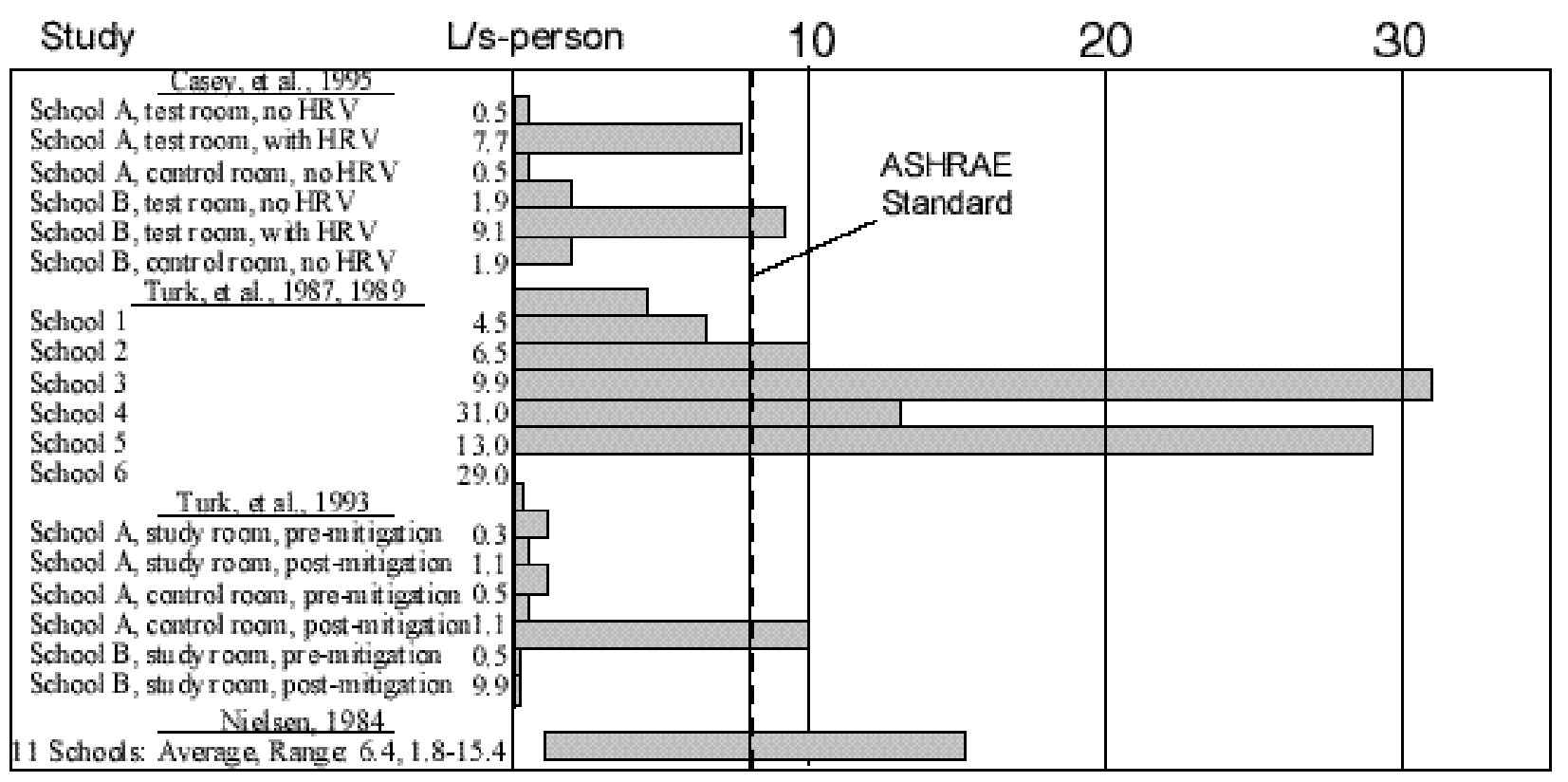

Figure 1. Ventilation rates and ranges reported in the published literature for U.S. and European schools. 


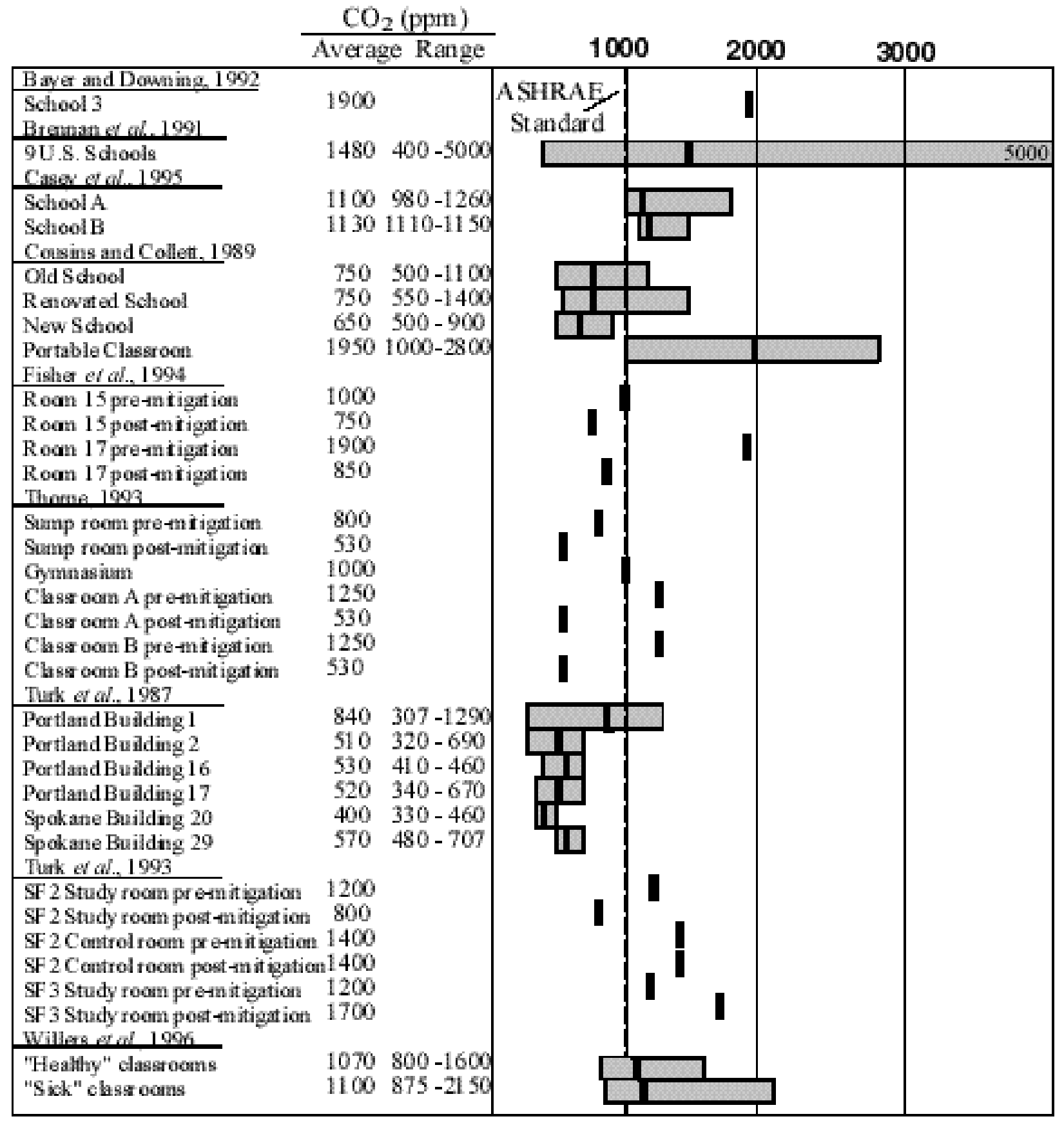

Figure 2. Average and ranges of $\mathrm{CO}_{2}$ concentrations in the scientific literature for U.S. and Canadian schools. 


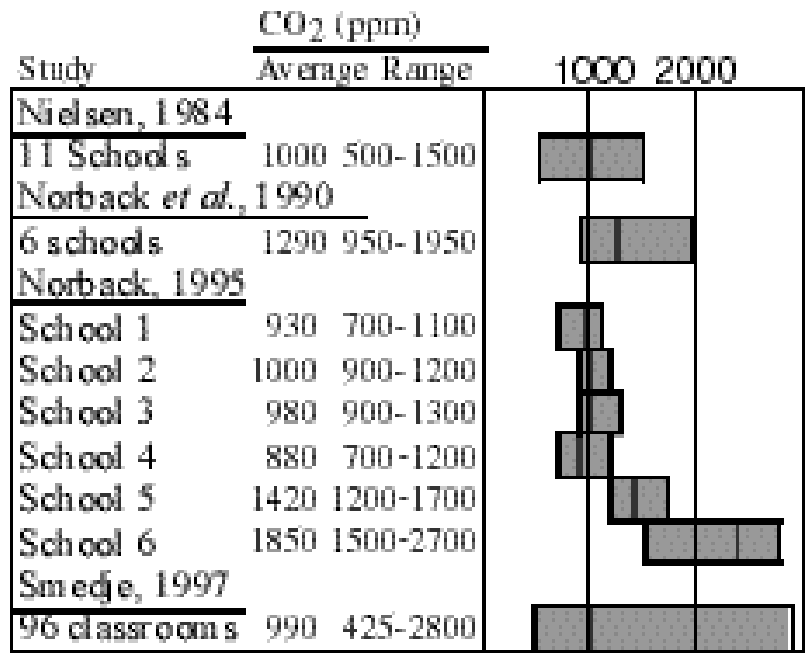

Figure 3. Average and ranges of $\mathrm{CO}_{2}$ concentrations reported in the scientific literature for European schools. 